\title{
Comparative Study On Concentration Of Some Minerals Found In Garlic (Allium Sativum Linn ) Species Grown In Some African Countries
}

\author{
Sa'adatu M. E. \\ Department of Chemical Technology, Standards Organisation of Nigeria Kaduna \\ Kaduna State, Nigeria \\ E-mail: saadatueri78@gmail.com
}

Mshelia M. S.

Applied Science Department,Kaduna Polytechnic, Kaduna

Received: August 23, 2012 Accepted: September 5, 2012

doi:10.5296/jbls.v4i1.2550

URL: http://dx.doi.org/10.5296/jbls.v4i1.2550

\begin{abstract}
The concentrations of some minerals: $\mathrm{K}, \mathrm{Ca}, \mathrm{P}, \mathrm{Mg}, \mathrm{Mn}$ and $\mathrm{Cu}$ found in garlic species grown in Nigeria, Senegal and Chad were determined using Atomic Absorption Spectroscopy. The results showed that Nigerian garlic specie contained the highest concentration of phosphorus $(1.29 \mathrm{mg} / \mathrm{L})$ and Copper $(0.017 \mathrm{mg} / \mathrm{L})$. Calcium was found to be highest in Senegalese garlic specie $(8.639 \mathrm{mg} / \mathrm{L})$ with the Nigerian specie having the second-highest recorded value $(6.930$ $\mathrm{mg} / \mathrm{L})$. The highest values of Potassium, Magnesium and Manganese content were recorded for Chadian garlic $(68.26 \mathrm{mg} / \mathrm{L}),(51.60 \mathrm{mg} / \mathrm{L})$ and $(0.212 \mathrm{mg} / \mathrm{L})$ respectively. The results obtained show that Senegalese garlic is rich in Calcium which is an essential mineral required for bone and teeth development, and also in the regulation of nervous excitability. Nigerian garlic is rich in Phosphorus which is a key component of the nucleic acids and also takes part in bone and teeth development; and Copper which plays an important part in blood clotting. The garlic specie from Chad is rich in Potassium, Magnesium and Manganese. Potassium plays an important role in maintaining $\mathrm{pH}$ balance and fluid distribution in the body; Magnesium in proper functioning of the muscles; Manganese is used in proper bone formation. Also from the results, there is reasonable variation in the concentration of the minerals, and this may be attributed to the types of soils on which the different garlic species were grown.
\end{abstract}

Keywords: Mineral elements, Garlic species, Allium sativum Linn African countries, Atomic 
Absorption Spectroscopy.

\section{Introduction}

Allium sativum Linn commonly called garlic in English is a perennial plant belonging to the family Liliaceae. The plant is also referred to with some common names such as stinking rose, nectar of the Gods and camphor of the poor (Dobelis, 1986). Cultivated throughout the world, garlic belongs to the same group of plants as onions (Allium cepa) and is mostly planted between the months of February and March in most countries in West Africa. The plant has a great healing power as it is used to treat ailments like hypertension, diarrhea, headache, dysentery, whooping cough, epilepsy (Murray, 1996). Garlic inhibits the growth of both bacteria and fungi (Orekhov et al., 1995). It provides protection against heart disease and strokes by lowering cholesterol and blood pressure (Murray, 1996). Fresh garlic is a source of numerous vitamins like vitamins B-6 and C, minerals like copper, zinc, iron, tin, calcium, manganese, magnesium, aluminium, germanium and selenium although their quantities may vary depending on the type of soil on which they are cultivated (Stephen and John, 2000). Garlic contains the highest sulphur content than any member of the genus Allium. Alliin is a sulphur containing compound that makes up the essential oil of garlic. It is mainly responsible for the pungent odor of garlic. Other sulphur containing compounds that make up garlic's essential oil include Diallyldisulphide (DADS) and Diallyltrisulphide (DATS). (Block, 1985).

Trace minerals are important in plants and animal nutrition. Mineral deficiencies lead to arthritis and muscular dystrophy. However, the number of trace minerals present in garlic is a direct function of the type of soil on which it is grown (Garlic Gourmet, 1997). This study is aimed at comparing the concentrations of some of these minerals in the commonest garlic species cultivated in Nigeria, Senegal and Chad.

\section{Materials and Methods}

\subsection{Plant Source and Sample Preparation}

The garlic species were collected from Sokoto (Nigeria), Ndjamena (Chad) and Senegal. They were dried at room temperature to constant weight. The dried garlics were ground into powder using motar and pistil. A portion (2.5g) of each sample was weighed and wet-digested using 25 $\mathrm{cm}^{3}$ of concentrated nitric acid and perchloric acid in separate beakers. The mixtures were heated over heating mantle until all fumes of the perchloric acid was given off. The mixture was allowed to cool at room temperature and filtered to remove undissolved particles. The filtrate was placed in three separate $100 \mathrm{~cm}^{3}$ standard flasks and made up to the marks with distilled water.

\subsection{Analytical Method}

Atomic Absorption Spectrophotometer (AAS), Perkin Elmer instrument (Analyst 400) was used to determine the concentration of the minerals. AAS is an analytical technique which measures the concentrations of elements in gaseous state. The technique makes use of the wavelength of light specifically absorbed by an element which corresponds to the energies needed to promote electrons from ground state to excited state. Samples in aqueous media are 
aspirated into a high temperature flame. The amount of light absorbed by the element or metal atom is proportional to the concentration of the element, and this relationship is known as BeerLambert's Law (Elmer, 1993)

\section{Results}

The results of the Atomic Absorption Spectroscopy of the minerals for the garlic samples collected in Nigeria, Senegal, and Chad are shown in Table 1.

Table 1. Concentration of mineral elements in garlic samples

\begin{tabular}{|c|c|c|c|c|}
\hline Sample(2.5g) & Country & Mineral Elements & $\begin{array}{l}\text { Concentration }(\mathrm{mg} / \mathrm{L}) \\
\pm 21.39 \text { stdev }\end{array}$ & $\%$ composition \\
\hline \multirow[t]{3}{*}{ Garlic } & Nigeria & $\begin{array}{l}\mathrm{Ca} \\
\mathrm{P} \\
\mathrm{K} \\
\mathrm{Mg} \\
\mathrm{Mn} \\
\mathrm{Cu}\end{array}$ & $\begin{array}{l}6.930 \\
0.28 \\
61.37 \\
26.89 \\
0.040 \\
0.017\end{array}$ & $\begin{array}{l}0.280 \\
0.010 \\
2.450 \\
1.080 \\
0.001 \\
6.8 \times 10^{-4}\end{array}$ \\
\hline & Chad & $\begin{array}{l}\mathrm{Ca} \\
\mathrm{P} \\
\mathrm{K} \\
\mathrm{Mg} \\
\mathrm{Mn} \\
\mathrm{Cu}\end{array}$ & $\begin{array}{l}6.227 \\
1.17 \\
68.26 \\
51.60 \\
0.212 \\
0.012\end{array}$ & $\begin{array}{l}0.249 \\
0.047 \\
2.730 \\
2.064 \\
0.008 \\
4.8 \times 10^{-4}\end{array}$ \\
\hline & Senegal & $\begin{array}{l}\mathrm{Ca} \\
\mathrm{P} \\
\mathrm{K} \\
\mathrm{Mg} \\
\mathrm{Mn} \\
\mathrm{Cu}\end{array}$ & $\begin{array}{l}8.639 \\
0.28 \\
61.56 \\
35.92 \\
0.068 \\
0.011 \\
\end{array}$ & $\begin{array}{l}0.346 \\
0.011 \\
2.462 \\
1.437 \\
0.003 \\
4.4 \times 10^{-4}\end{array}$ \\
\hline
\end{tabular}

\section{Discussion}

A notable variation was observed in the concentration of the minerals ( $\mathrm{Ca}, \mathrm{K}, \mathrm{Mg}, \mathrm{Mn}, \mathrm{P}$ and $\mathrm{Cu}$ ) in the different samples of the garlic assessed. From the results, phosphorus was found to have the highest concentration in Sokoto (Nigerian) garlic and the Senegalese garlic had the lowest. The Senegalese species of garlic was found to contain more of Calcium which was followed by the Nigerian and Chadian species respectively. In the same manner, Potassium, Magnessium and Manganese were found to be highest in the Chadian garlic species.

Research showed that the amount of trace minerals contained in garlic is a direct function of their presence in the soil on which they were grown (Stephen and John, 2000). The amount of sunlight, air, and water are also factors among others that cause variation in the concentration of the respective minerals studied (Stephen and John, 2000). Also garlic grown with artificial fertilizer contains smaller amount of these trace minerals than those grown organically in soils that have had their minerals replenished by conscientious growers (Stephen and John, 2000). 
Trace minerals are an integral part for healthy growth of both plants and animals. Calcium is needed for the development and maintenance of bones and the regulation of nervous excitability and muscular contraction. Calcium's effectiveness is enhanced by the presence of vitamins A, C, and D, Magnesium, Manganese, Phosphorus and Copper. The presence of potassium in the body together with sodium and chloride ion helps in maintaining fluid distribution and $\mathrm{pH}$ balance. Phosphorus is the second most abundant essential mineral in the body after potassium. Phosphorus is a key component of DNA, RNA (nucleic acids), bones, teeth, and many other compounds required for life.

\section{Conclusion}

The concentrations of the trace minerals under study in garlic species obtained from Nigeria, Senegal, and Chad have been analyzed and reported. The results obtained are in agreement with the W. H. O. guideline (1996) for allowed elemental concentrations in human nutrition. The low phosphorus content in the garlics is of great concern, this may be related to the fact that some of these soils are treated with artificial fertilizer which resulted in minute quantities available for absorption by the plants, and this is dependable on the amount of water present in the soil. The garlics grown in the three African Countries showed good nutritional values as the minerals studied compliment their respective roles in the body leading to a healthy nutritional balance.

\section{Acknowledgement}

The authors are grateful to Dr S. Garba of Chemistry Department, Nigerian Defense Academy Kaduna, Kaduna State, Nigeria for his valuable input throughout the composition of this paper.

\section{References}

Block, E. (1985). The Chemistry of Garlic and Onions. Sci. Am, 252(3),114-119. http://dx.doi.org/10.1038/scientificamerican0385-114

Dobelis, I. N. (1986). Magic and Medicine of Plants. The Reader's Digest Association; Pleasantville, New York.

Elmer, P. (1993). User's guide for Atomic Absorption Spectroscopy.

Gourmet Garlic Gardens. (1997). A primer on the Chemistry of Garlic. http://dx.doi.org/10.2135/cropsci1997.0011183X003700050003x

Murray, M. T. (1996). The Healing Power of Herbs. Rocklin, CA: Prima Publishing, 121-131.

Orekhov, A. N., Tertov, V. V., Sobenin, I. A. \& Pivovarova, E. M. (1995). "Direct anti-atherosclerosis-related effects of garlic.' Annals of Medicine, 27(1), 63-5. http://dx.doi.org/10.3109/07853899509031938

Pizzorno, J. E. \& Murray, M. T. (1996). "Allium Sativum." A Textbook of Natural Medicine. Bothell, W. A. Bastyr University Publications, 1.

Stephen, F. \& John, B. (2000). Garlic: Nature's Original Remedy. Published by Healing Arts Press of Rochester. 


\section{Copyright Disclaimer}

Copyright reserved by the author(s).

This article is an open-access article distributed under the terms and conditions of the Creative Commons Attribution license (http://creativecommons.org/licenses/by/3.0/). 